\title{
Cognitive, Behavioral, and Adaptive Profiles in Williams Syndrome With and Without Loss of GTF2IRD2
}

\author{
Carlos Alberto Serrano-Juárez, ${ }^{1}$ Carlos Alberto Venegas-Vega, ${ }^{2}$ Ma. Guillermina Yáñez-Téllez, ${ }^{1}$ \\ Mario Rodríguez-Camacho, ${ }^{1}$ Juan Silva-Pereyra, ${ }^{1}$ Hermelinda Salgado-Ceballos, ${ }^{3}$ And Belén Prieto-Corona ${ }^{1}$ \\ ${ }^{1}$ Laboratorio de Neurometría, Facultad de Estudios Superiores Iztacala, UNAM, Los Reyes Iztacala, Tlalnepantla, Estado de México, CP \\ ${ }^{2}$ Servicio de Genética, Hospital General de México "Dr. Eduardo Liceaga", Cuauhtémoc, CDMX, CP \\ ${ }^{3}$ Unidad de Investigación Médica en Enfermedades Neurológicas, Hospital de Especialidades, CMN "Siglo XXI", IMSS
}

(Received November 13, 2017; Final Revision June 15, 2018; AcCePTed July 23, 2018)

\begin{abstract}
Williams syndrome (WS) is a neurodevelopmental disorder that results from a heterozygous microdeletion on chromosome 7q11.23. Most of the time, the affected region contains $\sim 1.5 \mathrm{Mb}$ of sequence encoding approximately 24 genes. Some $5-8 \%$ of patients with WS have a deletion exceeding $1.8 \mathrm{Mb}$, thereby affecting two additional genes, including GTF2IRD2. Currently, there is no consensus regarding the implications of GTF2IRD2 loss for the neuropsychological phenotype of WS patients. Objectives: The present study aimed to identify the role of GTF2IRD2 in the cognitive, behavioral, and adaptive profile of WS patients. Methods: Twelve patients diagnosed with WS participated, four with GTF2IRD2 deletion (atypical WS group), and eight without this deletion (typical WS group). The age range of both groups was 7-18 years old. Each patient's 7q11.23 deletion scope was determined by chromosomal microarray analysis. Cognitive, behavioral, and adaptive abilities were assessed with a battery of neuropsychological tests. Results: Compared with the typical WS group, the atypical WS patients with GTF2IRD2 deletion had more impaired visuospatial abilities and more significant behavioral problems, mainly related to the construct of social cognition. Conclusions: These findings provide new evidence regarding the influence of the GTF2IRD2 gene on the severity of behavioral symptoms of WS related to social cognition and certain visuospatial abilities. (JINS, 2018, 24, 896-904)
\end{abstract}

Keywords: Williams syndrome, Visuospatial abilities, Neuropsychological phenotype, Neuropsychology, Social cognition, Chromosomal microarray

\section{INTRODUCTION}

Williams syndrome (WS) is a rare neurodevelopmental disorder caused by a microdeletion in the q11.23 region of chromosome 7. The incidence rate of its typical forms is $1 / 7000$ to 1/25,000 live births (Bellugi, Lichtenberger, Mills, Galaburda, \& Korenberg, 1999; Mervis \& Morris, 2007; Meyer-Linderberg, Mervis, \& Berman, 2006). The main clinical manifestations of WS are: (1) characteristic facial features (e.g., small upturned nose, long philtrum, wide mouth, and small chin); (2) supravalvular aortic stenosis (SVAS) and/or peripheral pulmonary artery stenosis (PPAS); and (3) an atypical neuropsychological phenotype characterized by a moderate to

Correspondence and reprint requests to: Belén Prieto-Corona, Av. De los Barrios No. 1, Los Reyes Iztacala, Tlalnepantla, Edo. Méx. 54090, México. E-mail: bemapado@gmail.com severe intellectual disability, severe impairment of visuospatial function, mild language impairment (Ferrero et al., 2010), and hypersociability (Bellugi et al., 1999). Most commonly (91-95\%), WS is a result of deletion of 1.5 megabases $(\mathrm{Mb})$ spanning a total of 24 genes. Near the middle of this deletion span is $E L N$, the gene that encodes elastin, mutations of which are associated with the SVAS/PPAS aspect of the syndrome (Mervis \& Morris, 2007; Osborne, 2010; Porter et al., 2012).

The WS neuropsychological profile is strongly associated with a severe impairment in visuospatial capacity (Capirci, Sabbadini, \& Volterra, 1996; Garayzábal, 2005; Garayzábal \& Cuetos, 2008). This visuospatial impairment could be consequent to the loss of genes involved in the structure and functions of the parietal cortex and the so-called dorsal stream of processing thought to carry location and motion information anterolaterally from primary visual cortex to parietal areas (Atkinson et al., 2001; Atkinson \& Braddick, 2012; 
Atkinson \& Nardini, 2008; García-Nonell, Rigau-Ratera, Artigas-Pallarés, García-Sánchez, \& Estévez-González, 2003). Some authors have found gray matter volume alterations or reductions in the dorsal occipitoparietal sulcus/vertical region of the intraparietal sulcus, which could explain, at least in part, dorsal stream vulnerability in WS (Atkinson, 2017; Atkinson \& Braddick, 2011; Meyer-Linderberg et al., 2004).

There has been increasing recognition of the variability in WS cognitive phenotype, including variability in intelligence (Tassabehji et al., 1999), executive functions (Morris et al., 2003), the expression of autistic-like features (Edelmann et al., 2007), and visuospatial abilities (Karmiloff-Smith et al., 2003). Advancements in genetic and molecular biology techniques, such as chromosomal microarrays (CMAs), can enable genomic alterations to be identified with higher precision than previously. Hence, the cognitive phenotype can be analyzed in combination with CMA data to determine the genes affected by each patient's deletion and thus help to explain the variability observed in the neuropsychological phenotypes of WS patients.

Studies conducted in animal models, as well as in patients with atypical deletions, have identified genes within the range of the WS microdeletion that could affect the neuropsychological phenotype of WS, including, from centromere to telomere (see Figure 1), FZD9, BAZ1B, STX1A, LIMK1, CLIP2, GTF2IRD1, and GTF2I (Botta et al., 1999; Frangiskakis et al., 1996; Gray, Karmiloff-Smith, Funnell, \& Tassabehji, 2006; Morris et al., 2003; Osborne, 2010; Vandeweyer, Van der Aa, Reyniers, \& Kooy, 2012; Wang, Spörle, Paperna, Schughart, \& Francke, 1999). These genes are known regulators of proteins related to localized structural and functional brain development (Broadbent et al., 2014; Gao et al., 2010; Karmiloff-Smith et al., 2012, 2003; Osborne, 2010; Tassabehji et al., 1999; Vandeweyer et al., 2012).

Most cases of WS (91-95\%) are associated with loss of GTF2I and GTF2IRD1, which are normally expressed in the cerebellum, hippocampus (Chailangkarn, Noree, \& Muotri, 2018), and intraparietal sulcus (Hoeft et al., 2014). Disruption of these genes has been associated with reduced fear and aggression (Young et al., 2008), altered visuomotor integration and visuospatial processing (Hirota et al., 2003; Hoeft et al., 2014), intellectual disability (Morris et al., 2003), and highly sociable behavior (Chailangkarn et al., 2018; Young et al., 2008).

A small minority (5-8\%) of patients with WS present with an atypical 1.8-Mb deletion that encompasses two additional genes, including GTF2IRD2, a member of the GTF2I gene family, whose members encode transcription factors required for synapse development and neurulation (Allen Brain Atlas, 2010; Makeyev et al., 2004; Tipney et al., 2004; Uhlén et al., 2015). The GTF2I gene family also includes $B E N$, a TFII-I family gene (Li et al., 2015). In mice, haploinsufficiency of TFII-I proteins results in a variety of phenotypic manifestations, including embryonic lethality and brain hemorrhage, as well as vasculogenic, craniofacial, and neural tube defects (Enkhmandakh et al., 2009).

GTF2IRD2 mRNA expression levels are high in the cerebral cortex, specifically in the prefrontal and parietal areas, as well as in the cerebellum (Allen Brain Atlas, 2010; Porter et al., 2012; Tipney et al., 2004; Uhlén et al., 2015). The protein encoded by GTF2IRD2 is also a TFII-I family protein (Makeyev et al., 2004) expressed in the brain (Tipney et al., 2004), specifically in parietal, frontal (orbitofrontal and dorsolateral) cortices and in the cerebellum (Allen Brain Atlas, 2010; Porter et al., 2012; Uhlén et al., 2015). GTF2IRD2 has been shown to regulate the activity of GTF2IRD1 and other TFII-I proteins during the postnatal period by direct interaction and sequestration of the proteins in a nuclear compartment (Palmer et al., 2012).

The aforementioned evidence indicates that disruption of GTF2I family genes in WS is associated with altered social behavior, negative emotionality, visuospatial ability, and intellectual ability (Crespi \& Hurd, 2014; Hoeft et al., 2014; Morris et al., 2003; Young et al., 2008). Meanwhile, GTF2IRD2, specifically, has been associated with visuospatial functioning, social reasoning, and cognitive flexibility (Porter et al., 2012). Therefore, we hypothesized that loss of

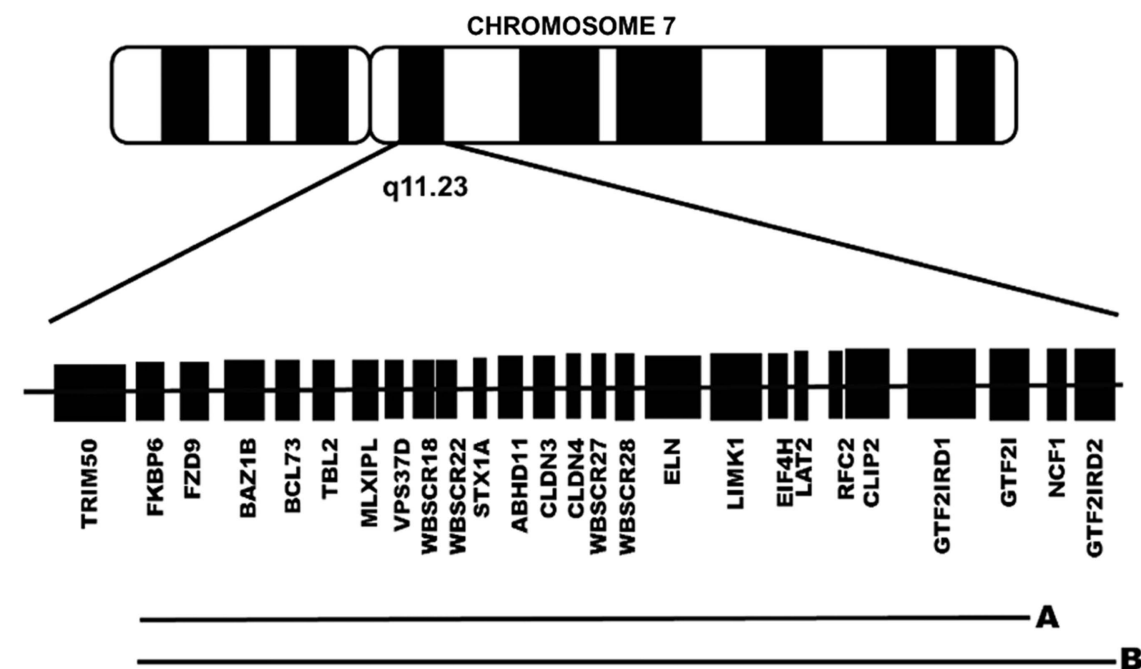

Fig 1. Schematic representation of the genes lost in the typical group of patients with a preserved GTF2IRD2 (1.5 Mb deletion) (A) and in the atypical group of patients without GTF2IRD2 (1.8 Mb deletion) (B). 
GTF2IRD2 may underlie visuospatial and social skill impairment severity in WS patients. To test this hypothesis in this study, we evaluated the cognitive, behavioral, and adaptive effects of GTF2IRD2 deletion in WS patients.

\section{METHODS}

\section{Participants}

Twelve patients ( 7 males) diagnosed with WS (age range, 7-18 years) were recruited from the Asociación Nacional de Síndrome de Williams A.C., the Asociación Viviendo con Sindrome de Williams A.C., and from the Genetics Service of the "Dr. Eduardo Liceaga" General Hospital of Mexico. All patients were living in the metropolitan area of Mexico City. Before starting the assessments, the parents of the participants signed written informed consent forms, and the patients' participation was approved by the ethics committee of the Faculty of Higher Education Iztacala, which adheres to the Helsinki Declaration.

Based on the CMA results (described below), patients were divided into a typical GTF2IRD2-retained group and an atypical GTF2IRD2-deleted group (Figure 1). The typical group consisted of 8 patients (5 males) with a $1.5-\mathrm{Mb}$ microdeletion and a chronological age (CA) mean of 11.5 years ( $S D, 3.59)$, including five who were in a special education program and four who had a perinatal complication. The atypical group consisted of 4 patients ( 2 males) with a 1.8-Mb microdeletion and mean CA of 12 years $(S D, 4.97)$, including one who was in a special education program, one who had a perinatal complication. None of the patients in either the typical group or the atypical group were taking medication. As shown in Supplementary Table $1 \mathrm{~S}$, the two groups were similar with respect to CA, mental age, full-scale IQ (FSIQ), and number of completed years of education (Mann Whitney $U$, all $p>.05$ ). Exact Fisher tests revealed no significant between-group differences with respect to gender constitution $(p=.57)$, special education rate $(p=$ $.27)$, and perinatal complication rate $(p=.42)$.

\section{Setting and Procedures}

A geneticist conducted a clinical assessment of each participant and evaluated his or her CMA results. A trained neuropsychologist conducted a neuropsychological evaluation in two 1.5-hr sessions in a cubicle at the Genetics Services of the "Dr. Eduardo Liceaga" General Hospital of Mexico. The CMA results were revealed to the neuropsychologist after all neuropsychological tests were completed. All assessments were conducted in Spanish, and Spanish-language neuropsychological instruments were used.

\section{Genetic Assessment}

In the geneticist's office, a blood sample was obtained from each participant for CMA Cyto-Scan Optima analysis to determine his or her $7 q 11.23$ microdeletion scope. This genetic analysis technique is based on nucleic acid hybridization and fluorescence analysis of imaged chromosomes (Venegas Vega, 2012).

\section{Neuropsychological Instruments}

To obtain each participant's clinical history, a structured interview was carried out to collect information about each patient's personal (pathological and non-pathological), hereditary-familial, and developmental history. The Wechsler Intelligence Scale for Children, $4^{\text {th }}$ edition (WISC-IV; Wechsler, 2007) and the Wechsler Adult Intelligence Scale, $4^{\text {th }}$ edition (WAIS-IV; Wechsler, 2014) were administered to evaluate the intelligence of patients who were $\leq 17$ years of age and of patients who were 17-18 years of age, respectively. The following WISC-IV/WAIS-IV scales were considered: Verbal Comprehension Index (VCI), Perceptual Reasoning Index (PRI), Working Memory Index (WMI) and Processing Speed Index (PSI), and FSIQ. Attention, memory, and executive function were evaluated with the NEUROPSI Attention and Memory subtests (Ostrosky-Solís, GuevaraLópez, \& Matute, 2012) and the Child Neuropsychological Assessment 2 (Evaluación Neuropsicológica Infantil, ENI-2) (Matute, Rosselli, \& Ardilla, 2014). Visual-spatial processing ability was assessed with the Developmental Test of Visual Perception, $3^{\text {rd }}$ edition (DTVP3), which uses the Frostig perception evaluation method (Hammill, Pearson, \& Voress, 2016).

To detect a wide range of emotional and behavioral problems, parents of the WS patients completed the family questionnaire of the Assessment System for Children and Adolescents (Sistema de Evaluación de Niños y Adolescentes (SENA) (Fernández-Pinto, Santamaría, SánchezSánchez, Carrasco, \& Del Barrio, 2015). The SENA measures internalizing problems (e.g., depression, anxiety, social anxiety), externalizing problems (e.g., hyperactivity and impulsivity, attention problems, aggressiveness), specific problems (e.g., developmental delays, learning disabilities), areas of vulnerability, and psychological resources. Finally, parents also completed the Adaptive Behavior Assessment System, $2^{\text {nd }}$ edition (ABAS-II) parent form (Harrison \& Oakland, 2008); the ABAS-II provides a complete assessment of adaptive skills across the lifespan.

\section{Statistical Analysis}

Mann Whitney $U$ tests were used to evaluate intergroup differences in neuropsychological test scores because the cohort was too small to produce parametric datasets. Due to this study's the small size, no $p$-level adjustment for multiple comparisons was made. Nevertheless, we calculated Cohen's $d$ statistical values for each between-group comparison result, such that $d=0.2$ was considered to represent a small effect, 0.5 a medium effect, and 0.8 a large effect. We analyzed the 
Table 1 . Comparison of DTVP-3 between atypical and typical WS group

\begin{tabular}{|c|c|c|c|c|c|c|c|c|c|}
\hline \multirow[b]{2}{*}{ Variable } & \multicolumn{3}{|c|}{ Typical group } & \multicolumn{3}{|c|}{ Atypical group } & \multicolumn{2}{|c|}{ Mann Whitney U } & \multirow[b]{2}{*}{ Cohen's $d$} \\
\hline & $M$ & $S D$ & Mean rank & $M$ & $S D$ & Mean rank & $\mathrm{U}$ & $p$-Value & \\
\hline Visual-motor integration index & 59.17 & 13.39 & 5.67 & 57.50 & 14.15 & 5.25 & 11.00 & .91 & 0.14 \\
\hline Eye-hand coordination & 2.17 & 1.94 & 5.83 & 2.25 & 2.50 & 5.00 & 10.00 & .76 & 0.27 \\
\hline Copying & 4.33 & 2.80 & 5.83 & 3.75 & 2.63 & 5.00 & 10.00 & .76 & 0.27 \\
\hline Reduced motor response index & 85.00 & 4.34 & 7.08 & 73.75 & 9.95 & 3.13 & 2.50 & .04 & $1.67^{\mathrm{a}}$ \\
\hline Figure-ground & 8.17 & 1.83 & 5.83 & 7.75 & 2.22 & 5.00 & 10.00 & .76 & 0.27 \\
\hline Visual closure & 3.50 & 0.84 & 7.17 & 2.00 & 0.82 & 3.00 & 2.00 & .04 & $1.83^{\mathrm{a}}$ \\
\hline Form constancy & 10.83 & 1.17 & 7.00 & 7.50 & 3.32 & 3.25 & 3.00 & .07 & $1.53^{\mathrm{a}}$ \\
\hline General visual perception index & 74.17 & 7.22 & 6.33 & 67.00 & 9.83 & 4.25 & 7.00 & .35 & 0.72 \\
\hline
\end{tabular}

Note: Two participants did not perform the DTVP-3 because they did not return.

${ }^{\mathrm{a}}$ Large effect size.

standardized scores obtained on all administered neuropsychological instruments.

\section{RESULTS}

Participants in both groups obtained FSIQ scores in the range of 40 to 60. No intergroup differences were found in any of the WISC-IV/WAIS-IV indices, nor in the NEUROPSI attention and memory test or the ENI-2 Executive Function scale. The two groups had similar verbal ability scores. On the other hand, a tendency toward lower cognitive performance was observed in the atypical GTF2IRD2-deleted group, relative to the typical group, especially in the tests that assess cognitive flexibility. The results of the intergroup comparison can be seen in Supplementary Tables S2-S4.

In DTVP-3 (Table 1), the typical group $(\bar{X}=3.5 ; S D=$ $0.84)$ performed better on the Visual Closure subtest than the atypical group $(\bar{X}=2.00 ; S D=0.82)$, with a large effect size $(U=2 ; p=.04 ; d=1.83)$. The typical group $(\bar{X}=$ $10.83 ; S D=1.17$ ) showed a non-significant trend toward performing better than the atypical group $(\bar{X}=7.5 ; S D=$ 3.32) on the Form Consistency subtest, with a large effect size $(U=3 ; p=.07 ; d=1.53)$. Relative to the typical group $(\bar{X}=85 ; S D=4.34)$, the atypical group $(\bar{X}=73.75$; $S D=9.95)$ had greater alterations in the Reduced Motor Response Index, of which the Visual Closure and Form Consistency subtests are components, with a large effect size $(U=2.5 ; p=.04 ; d=1.67)$. Note that for this index perceptual abilities are highly weighted given the limited use of motor skills in the execution of its subtests.

In the SENA inventory, the atypical group $(\bar{X}=80.75$; $S D=10.72)$ scored higher than the typical group $(\bar{X}=$ 59.75; $S D=15.58)$ on the Isolation scale, with a large effect size $(U=4 ; p=.04 ; d=1.46)$, suggesting that atypical patients spend more time alone (Table 2). In the same way, the typical group $(\bar{X}=52.88 ; S D=9.51)$ performed better than the atypical group $(\bar{X}=36.25 ; S D=3.40)$ on the Emotional Intelligence scale of the SENA, with a large effect size $(U=1 ; p=.01 ; d=2.17)$, evidencing better social skills and behaviors of the typical group compared to the atypical group. Analyzing the items that make up the SENA Emotional Intelligence and Isolation scales, we found that, compared to the typical group, the atypical group present greater deficiencies in several constructs of social cognition (Adolphs, 2009), including emotional recognition (e.g., "When I feel bad, he/she notices"), empathy (e.g., "Pay attention to how others feel"), and theory of mind (e.g., "Knows how to put themselves in the another's place").

Finally, the typical group $(\bar{X}=6.75 ; S D=3.06)$ also performed significantly better than the atypical group $(\bar{X}=$ 2.25; $S D=2.50$ ) on the ABAS-II Leisure scale, with a large effect size $(U=4 ; p=.04 ; d=1.46)$. Furthermore, the typical group $(\bar{X}=8.88 ; S D=2.10)$ also performed better on the ABAS-II Social scale than the atypical group $(\bar{X}=5$; $S D=2.71)$, with a large effect size $(U=3 ; p=.02 ; d=$ 1.65). The poorer social skills of the atypical group relative to the typical group are consistent with a greater deficit in social cognition, which could be related to the loss of GTF2IRD2 (Table 3).

\section{DISCUSSION}

Our typical group with loss of GTF2I/GTF2IRD1 showed a neuropsychological phenotype characteristic of WS, whereas our atypical group, whose $1.8-\mathrm{Mb}$ deletion resulted in the additional loss of GTF2IRD2, exhibited certain visuospatial/ perception and social cognition alterations together with a reduced ability to socialize. GTF2IRD2 has been observed to have a genetic regulatory influence on GTF2I and GTF2IRDI (Palmer et al., 2012); all three of these genes are expressed in frontal and parietal cortices, and the cerebellum (Allen Brain Atlas, 2010; Porter et al., 2012; Tipney et al., 2004; Uhlén et al., 2015). Considering the present results, we posit that the loss of this group of genes, and the consequent loss of the availability of the proteins encoded by these genes in the prefrontal cortex, parietal cortex, and cerebellum, where they are normally highly expressed, led to greater cognitive impairments than is typical of WS.

We found that both groups had similar cognitivebehavioral phenotypes with respect to verbal abilities. This 
Table 2 . Comparison of SENA between atypical and typical WS group

\begin{tabular}{|c|c|c|c|c|c|c|c|c|c|}
\hline \multirow[b]{2}{*}{ Variable } & \multicolumn{3}{|c|}{ Typical group } & \multicolumn{3}{|c|}{ Atypical group } & \multicolumn{2}{|c|}{ Mann Whitney U } & \multirow[b]{2}{*}{ Cohen's $d$} \\
\hline & $M$ & $S D$ & Mean rank & $M$ & $S D$ & Mean rank & $\mathrm{U}$ & $p$-Value & \\
\hline \multicolumn{10}{|l|}{ Index scores } \\
\hline Global problems index & 54.50 & 16.48 & 6.25 & 53.00 & 4.76 & 7.00 & 14.00 & .81 & 0.27 \\
\hline Emotional problems index & 52.13 & 15.67 & 6.25 & 49.25 & 4.99 & 7.00 & 14.00 & .81 & 0.27 \\
\hline Behavioral problems index & 54.13 & 14.33 & 6.38 & 52.75 & 5.56 & 6.75 & 15.00 & .93 & 0.41 \\
\hline Executive functions index & 55.75 & 11.99 & 6.00 & 57.25 & 4.03 & 7.50 & 12.00 & .57 & 0.40 \\
\hline Personal sources index & 44.38 & 11.56 & 7.38 & 36.25 & 8.02 & 4.75 & 9.00 & .28 & 0.73 \\
\hline \multicolumn{10}{|l|}{ Clinical scales } \\
\hline Depression & 57.13 & 22.74 & 6.56 & 51.75 & 7.54 & 6.38 & 15.50 & .93 & 0.05 \\
\hline Anxiety & 57.25 & 16.26 & 6.50 & 52.50 & 3.32 & 6.50 & 16.00 & 1 & 0.00 \\
\hline Social anxiety & 42.00 & 9.56 & 5.63 & 45.50 & 6.14 & 8.25 & 9.00 & .28 & 0.73 \\
\hline Somatic complaints & 50.50 & 7.86 & 6.56 & 48.25 & 8.96 & 6.38 & 15.50 & .93 & 0.05 \\
\hline Attention problems & 58.38 & 9.62 & 6.31 & 61.50 & 4.80 & 6.88 & 14.50 & .81 & 0.15 \\
\hline Hyperactivity & 53.75 & 8.55 & 5.94 & 55.75 & 3.10 & 7.63 & 11.50 & .46 & 0.45 \\
\hline Anger management problems & 56.50 & 17.05 & 6.94 & 49.50 & 10.38 & 5.63 & 12.50 & .57 & 0.35 \\
\hline Aggression & 52.25 & 12.97 & 5.88 & 54.50 & 9.81 & 7.75 & 11.00 & .46 & 0.51 \\
\hline Behavioral disruptive & 50.75 & 9.78 & 6.25 & 53.75 & 1.26 & 7.00 & 14.00 & .81 & 0.20 \\
\hline Unusual behavior & 63.25 & 14.85 & 6.25 & 69.00 & 24.15 & 7.00 & 14.00 & .81 & 0.20 \\
\hline \multicolumn{10}{|l|}{ Vulnerability scales } \\
\hline Emotional regulation problems & 56.25 & 13.99 & 6.63 & 53.50 & 7.42 & 6.25 & 15.00 & .93 & 0.10 \\
\hline Rigidity & 49.13 & 9.93 & 6.00 & 52.00 & 7.35 & 7.50 & 12.00 & .57 & 0.40 \\
\hline Isolation & 59.75 & 15.58 & 5.00 & 80.75 & 10.72 & 9.50 & 4.00 & .04 & $1.46^{\mathrm{a}}$ \\
\hline \multicolumn{10}{|l|}{ Personal sources scales } \\
\hline Social integration & 45.75 & 10.51 & 7.31 & 38.75 & 9.64 & 4.88 & 9.50 & .28 & 0.67 \\
\hline Emotional Intelligence & 52.88 & 9.51 & 8.38 & 36.25 & 3.40 & 2.75 & 1.00 & .01 & $2.17^{\mathrm{a}}$ \\
\hline Disposition to the study & 38.75 & 17.43 & 6.44 & 40.50 & 5.80 & 6.63 & 15.50 & .93 & 0.05 \\
\hline
\end{tabular}

${ }^{\mathrm{a}}$ Large effect size.

Table 3. Comparison of ABAS-II between atypical and typical WS group

\begin{tabular}{|c|c|c|c|c|c|c|c|c|c|}
\hline \multirow[b]{2}{*}{ Variable } & \multicolumn{3}{|c|}{ Typical group } & \multicolumn{3}{|c|}{ Atypical group } & \multicolumn{2}{|c|}{ Mann Whitney U } & \multirow[b]{2}{*}{ Cohen's $d$} \\
\hline & $M$ & $S D$ & Mean rank & $M$ & $S D$ & Mean rank & $\mathrm{U}$ & $p$-Value & \\
\hline \multicolumn{10}{|l|}{ Areas } \\
\hline Communication & 3.88 & 3.23 & 6.69 & 2.75 & 1.71 & 6.13 & 14.50 & .81 & 0.15 \\
\hline Academic skill & 1.00 & 0.00 & 6.00 & 1.50 & 1.00 & 7.50 & 12.00 & .57 & 0.40 \\
\hline Self-direction & 6.50 & 3.66 & 7.69 & 3.00 & 2.45 & 4.13 & 6.50 & .11 & 1.05 \\
\hline Leisure & 6.75 & 3.06 & 8.00 & 2.25 & 2.50 & 3.50 & 4.00 & .04 & $1.46^{\mathrm{a}}$ \\
\hline Social & 8.88 & 2.10 & 8.13 & 5.00 & 2.71 & 3.25 & 3.00 & .02 & $1.65^{\mathrm{a}}$ \\
\hline Use of community resources & 3.88 & 3.68 & 6.63 & 3.50 & 3.00 & 6.25 & 15.00 & .93 & 0.10 \\
\hline Home life & 7.50 & 3.16 & 6.94 & 6.50 & 3.87 & 5.63 & 12.50 & .57 & 0.35 \\
\hline Health and security & 6.00 & 3.59 & 7.44 & 3.25 & 2.63 & 4.63 & 8.50 & .21 & 0.79 \\
\hline Self-care & 4.50 & 2.78 & 7.50 & 2.50 & 1.29 & 4.50 & 8.00 & .21 & 0.85 \\
\hline \multicolumn{10}{|l|}{ Index scores } \\
\hline Conceptual index & 66.63 & 9.61 & 7.38 & 59.50 & 6.56 & 4.75 & 9.00 & .28 & 0.73 \\
\hline Social index & 86.88 & 9.75 & 8.13 & 67.25 & 12.69 & 3.25 & 3.00 & .02 & $1.65^{\mathrm{a}}$ \\
\hline Practical index & 72.38 & 13.36 & 7.44 & 62.25 & 8.22 & 4.63 & 8.50 & .21 & 0.79 \\
\hline General adaptive coefficient & 71.63 & 11.21 & 7.69 & 61.50 & 8.27 & 4.13 & 6.50 & .10 & 1.05 \\
\hline
\end{tabular}

${ }^{\mathrm{a}}$ Large effect size.

sparing of verbal abilities may be related to the low-density of expression of GTF2IRD2 in temporal areas (Allen Brain Atlas, 2010; Colantuoni et al., 2011; Uhlén et al., 2015;
Zhang et al., 2014). Meanwhile, we found that GTF2IRD2 deletion in WS was associated with impairments in visuospatial skills and social cognition. These results suggest that 
GTF2IRD2 may contribute to the severity of the neuropsychological phenotype of WS, especially with respect to deficiencies in some visuospatial abilities and some aspects of social cognition.

Concerning visuospatial ability, patients with a GTF2IRD2 deletion showed reduced visual closure capacity, compared to patients in whom the gene was conserved. This ability is related to recognition of how components of a unit are associated to form a figure (Frostig, 1999). Formerly, Porter et al. (2012) found low scores on spatial tasks in nine WS patients who lost this gene. However, in the present study, we found specifically that visual closure ability, form consistency, and figure-grounding, tasks that do not include a motor component and that form the reduced motor response index, are weaknesses in these patients. These findings support the notion that the GTF2IRD2 deletion phenotype may have more of a perceptual component than a visual-motor one.

Additionally, visual closure capacity has been found to be related to global attention tasks (D'Souza, Booth, Connolly, Happe, \& Karmiloff-Smith, 2016; Porter \& Coltheart, 2006). Dorsal stream vulnerability theory encompasses visual closure capacity together with navigation capacity, use of spatial labels, and visuoconstructive (Atkinson, 2017; Atkinson et al., 2001; Atkinson \& Braddick, 2011, 2012; Atkinson \& Nardini, 2008). According to this theory, there are two perceptual networks: (1) the ventral stream responsible for object and face recognition, which is retained in patients with WS; and (2) the dorsal stream associated with object location and spatial management (Atkinson, 2017).

Several studies have provided evidence suggesting that the dorsal stream is related to occipito-parietal networks, specifically the intraparietal sulcus, precuneus, and inferior and superior parietal gyrus (Kravitz, Saleem, Baker, \& Mishkin, 2011; Meyer-Linderberg et al., 2004). Global ability and closure have also been reported to be related to intraparietal sulcus alterations (Atkinson, 2017; Meyer-Linderberg et al., 2004; Mobbs et al., 2007). Our finding of impaired visual closure in WS patients without GTF2IRD2 are consistent with prior findings showing that, like patients with right parietal lobe lesions, WS patients can identify and copy the elements of visual stimuli, but fail to integrate them into a whole (global process) (Atkinson et al., 2001; Atkinson \& Braddick, 2012; Atkinson \& Nardini, 2008). Hence, dorsal stream vulnerability theory (Atkinson \& Nardini, 2008) could explain the greater visuospatial alterations in people with WS associated with loss of GTF2IRD2, relative to typical WS patients.

In this context, it is noteworthy that both the parietal cortex and cerebellum, areas with unusually high GTF2IRD2 expression (Allen Brain Atlas, 2010; Porter et al., 2012; Uhlén et al., 2015), are involved in visuospatial ability and are altered markedly in WS (Martens, Wilson, \& Reutens, 2008). The parietal and prefrontal cortices in the right hemisphere have been associated with the recognition of emotions in faces, judgment about them, theory of mind, and empathy (Adolphs, 2009; Shamay-Tsoory, Tomer, Goldsher, Berger,
\& Aharon-Peretz, 2004). Structural and functional alterations have been found in the amygdala and right orbital-medial prefrontal cortex of WS patients performing tasks that evaluate these domains of social cognition (Bellugi et al., 2007; Mimura et al., 2010). WS patients perform similarly to patients with right parietal damage on visuospatial tasks (Atkinson et al., 2001; Atkinson \& Braddick, 2012; Atkinson \& Nardini, 2008); this greater deficit may be associated with lower visuospatial and social performance in those patients with a GTF2IRD2 deletion.

Regarding behavioral profile, our finding that patients with a GTF2IRD2 deletion presented several behavioral problems associated with social cognition indicate considerable challenges for these patients in appropriate expression of empathy, recognition of the emotional state of another, and theory of mind. This finding is consistent with previous results of Porter et al. (2012), who identified more difficulties in theory of mind tasks in patients with lost, versus retained, GTF2IRD2. Likewise, individual case reports of WS patients with co-deletion of GTF2I, GTF2IRD1, and GTF2IRD2 described predominant autistic features (Edelmann et al., 2007; Karmiloff-Smith et al. 2012). Conversely, our adaptive skills scale results may indicate better social abilities performance and leisure activities in WS patients with conserved GTF2IRD2, and their relatively superior performance in these areas may be related to the preservation of their ability to perceive others' emotions and their more typical performance on tests of theory of mind and empathy.

\section{Limitations}

It is important to emphasize that in this study we did not apply specific or experimental tests that assessed the patients' cognitive-emotional abilities directly. However, the results of the inventories completed by the parents had moderate to large effect sizes. The limitations of this study include: (1) a lack of neuroimaging studies, which could identify structural inter-hemispheric differences (especially in the parietal and frontal cortices and in the cerebellum) associated with visuospatial processes and social cognition; (2) a lack of psychological and experimental tests that assess the components of social cognition directly; and (3) a small sample, which precludes a strong statistical analysis and limits the generalizability of the results. Notwithstanding, this work provides an approach to examining the relationship among genes, brain, cognition, and behavior in WS patients.

\section{CONCLUSION}

The present findings provide new evidence of the importance of GTF2IRD2 in the cognitive, behavioral, and adaptive phenotypes of WS patients. The results support the notion that the locally elevated expression of GTF2IRD2 in the right prefrontal and parietal cortices, when the gene is present, 
reflect its role in the cognitive, behavioral, and adaptive functions that are impaired in WS patients with deletion of GTF2IRD2. Furthermore, given GTF2IRD2's regulatory influence on GTF2IRD1, loss of GTF2IRD2 may result in structural alterations in sites where GTF2IRDI is normally expressed, leading to more profound effects on visuospatial and social skills. It is necessary to continue studying the phenotypic outcomes associated with different deletion variants in WS patients to identify the neuropsychological influence of specific genes affected in WS.

\section{ACKNOWLEDGMENTS}

All authors involved in this investigation declare no conflicts of interest. PAPIIT IA301916 and CONACYT CVU 478060 supported this work. We thank The Asociación Nacional de Síndrome de Williams A.C., The Asociación Viviendo con Síndrome de Williams A.C., and Genetics Service of the "Dr. Eduardo Liceaga" General Hospital of Mexico. Dr. Hermelinda Salgado-Ceballos thanks the IMSS Foundation for the scholarship of excellence received.

\section{SUPPLEMENTARY MATERIALS}

To view supplementary material for this article, please visit https://doi.org/10.1017/S1355617718000711

\section{REFERENCES}

Adolphs, R. (2009). The social brain: Neural basis of social knowledge. Annual Review of Psychology, 60, 693-716. doi: 10.1146/annurev.psych.60.110707.163514

Allen Brain Atlas. (2010). Allen Institute for Brain Science. Retrieved from human.brain-map.org

Atkinson, J. (2017). Visual brain development: A review of "Dorsal stream vulnerability"- motion, mathematics, amblyopia, actions, and attention. Journal of Vision, 17(3), 1-24. doi: 10.1167/17.3.26

Atkinson, J., Anker, S., Braddick, O., Nokes, L., Mason, A., \& Braddick, F. (2001). Visual and visuospatial development in young children with williams syndrome. Developmental Medicine \& Child Neurology, 43, 330-337.

Atkinson, J., \& Braddick, O. (2011). From genes to brain development to phenotypic behavior: "Dorsal-stream vulnerability" in relation to spatial cognition, attention, and planning of actions in Williams syndrome (WS) and other development disorders. Progress in Brain Research, 189, 261-283. doi: 10.1016/B978-0-444-53884-0.00029-4

Atkinson, J., \& Braddick, O. (2012). Visual attention in the first years: Typical development and develompental disorders. Development Medicine \& Child Neurology, 54, 589-595. doi: 10.1111 /j.469-8749.2012.04294.x

Atkinson, J., \& Nardini, M. (2008). The neuropsychology of visuospatial and visuomotor development. In J. Reed \& J. Warner-Rogers (Eds.), Child neuropsychology: Concepts, theory and practice (pp. 183-217). Chichester, UK: WileyBlackwell.

Bellugi, U., Järvinen-Pasley, A., Doyle, T., Reilly, J., Reiss, A., \& Korenberg, J. (2007). Affect, Social Behavior, and the Brain in
Williams Syndrome. Current Directions in Psychological Science, 16(2), 99-104.

Bellugi, U., Lichtenberger, L., Mills, D., Galaburda, A., \& Korenberg, J. (1999). Briding cognition, the brain and molecular genetics: Evidence from Williams syndrome. Trends in Neuroscience, 22, 197-207.

Botta, A., Novelli, G., Mari, A., Sabani, M., Korenberg, J., Osborne, L., ... Dallapiccola, B. (1999). Detection of an atypical 7q11.23 deletion in Williams syndrome patients which does not include the STX1A and FZD3 genes. Journal of Medical Genetics, 36, 478-480. doi: 10.1136/jmg.36.6.478

Broadbent, H., Farran, E., Chin, E., Metcalfe, K., Tassabehji, M., Turnpenny, P., ... Karmiloff-Smith, A. (2014). Genetic contributions to visuospatial cognition in Williams syndrome: Insights from two contrasting partial deletion patients. Journal of Neurodevelopmental Disorders, 6, 18.

Capirci, O., Sabbadini, L., \& Volterra, V. (1996). Language development in Williams syndrome: A case study. Cognitive Neuropsychology, 1017-1039.

Chailangkarn, T., Noree, C., \& Muotri, A. R. (2018). The contribution of GTF2I haploinsufficiency to Williams syndrome. Molecular and Cellular Probes, 40, 45-51. doi: https://doi.org /10.1016/j.mcp.2017.12.005

Colantuoni, C., Lipska, B. K., Hyde, T. M., Tao, R., Leek, J. T., Colantuoni, E. A., ... Kleinman, J. E. (2011). Temporal dynamics and genetic control of transcription in the human prefrontal cortex. Nature, 478, 519-523. doi: 10.1038/ nature 10524

Crespi, B. J., \& Hurd, P. L. (2014). Cognitive-behavioral phenotypes of Williams syndrome are associated with genetic variation in the GTF2I gene, in a healthy popoulation. BMC Neuroscience, 15, 127.

D’Souza, D., Booth, R., Connolly, M., Happe, F., \& KarmiloffSmith, A. (2016). Rethinking the concepts of 'local or global processors': Evidence from Williams syndrome, Down syndrome, and Autism Spectrum Disorders. Developmental Science, 19(3), 452-468. doi: 10.1111/desc.12312

Edelmann, L., Prosnitz, A., Pardo, S., Bhatt, J., Cohen, N., Lauriat, T., ... McInnes, A. (2007). An atypical deltion of the WilliamsBeuren syndrome interval implicates genes associated with defective visuospatial processing and autism. Journal of Medical Genetics, 44, 136-143. doi: 10.1136/jmg.2006.044537

Enkhmandakh, B., Makeyev, A., Erdenechimeg, L., Ruddle, F., Chimge, N.-O., Tussie-Luna, M. I., ... Bayarsaihan, D. (2009). Essential functions of the Williams-Beuren syndrome-associated TFII-I genes in embryonic development. Proceedings of the National Academy of Sciences of the United States of America, 106(1), 181-186. doi: 10.1073pnas.0811531106

Fernández-Pinto, I., Santamaría, P., Sánchez-Sánchez, F., Carrasco, M. A., \& Del Barrio, V. (2015). Sistema de Evaluación de Niños y Adolescentes. SENA. Madrid: TEA Ediciones.

Ferrero, G., Howald, C., Micale, L., Biamino, E., Augello, B., Fusco, C., ... Merla, G. (2010). An atypical 7q11.23 deletion normal IQ Williams-Beuren syndrome patient. European Journal of Human Genetics, 18, 33-38.

Frangiskakis, M., Ewart, A., Morris, C. A., Mervis, C., Bertrand, J., Robinson, B., ... Keating, M. T. (1996). LIM-kinase1 hemizygosity implicated in impaired visuospatial cosntructive cognition. Cell, 86, 59-69.

Frostig, M. (1999). Figuras y Formas: Guía del Maestro. México: Panamericana. 
Gao, M., Bellugi, U., Dai, L., Mills, D., Sobel, E., Lange, K., \& Korenberg, J. (2010). Intelligence in Williams Syndrome is related to STX1A, which encodes a component of the presynaptic SNARE complex. PLoS One, 5(4), e10292. doi: 10.1371/journal. pone.0010292

Garayzábal, E. (2005). Síndrome de Williams: Materiales y análisis pragmático. Valencia: Universitat de Valencia.

Garayzábal, E., \& Cuetos, F. (2008). Aprendizaje de la lectura en los niños con síndrome de Williams. Psicothema, 20(4), 672-677.

García-Nonell, C., Rigau-Ratera, E., Artigas-Pallarés, J., GarcíaSánchez, C., \& Estévez-González, A. (2003). Síndrome de Williams: Memoria, funciones visuoespaciales y funciones visuoconstructivas. Revista de Neurología, 37, 826-830.

Gray, V., Karmiloff-Smith, A., Funnell, E., \& Tassabehji, M. (2006). In-depht analysis of spatil cognition in Williams syndrome: A critical assessment of the role of the LIMK1 gene. Neuropsychologia , 44, 679-685. doi: 10.1016/j.neuropsychologia. 2005.08.008

Hammill, D., Pearson, N., \& Voress, J. (2016). DTVP-3: Método de evaluación de la percepción visual de Frostig. México: Manual Moderno.

Harrison, P., \& Oakland, T. (2008). Sistema para la Evaluación de la Conducta Adaptativa (ABAS II). Madrid: TEA Ediciones.

Hirota, H., Matsuoka, R., Chen, X.-N., Salandanan, L., Lincoln, A., Rose, F., ... Korenberg, J. (2003). Williams syndrome deficits in visual spatial processing linked to GTF2IRD1 and GTF2I on chromosome 7q11.23. Genetics in Medicine, 5(4), 311-321. doi: 10.1097/01.GIM.0000076975.10224.67

Hoeft, F., Dai, L., Haas, B. W., Sheau, K., Mimura, M., Mills, D., ... Reiss, A. (2014). Mapping genetically controlled neural circuits of social behavior and visuo-motor integration by a preliminary examination of atypical deletions with Williams syndrome. PLoS One, 9(8). doi: e104088. doi:10.1371/journal.pone.0104088

Karmiloff-Smith, A., Broadbent, H., Farran, E., Longhi, E., D’Souza, D., Metcalfe, K., ... Sansbury, F. (2012). Social cognition in Williams Syndrome: Genotype/phenotype insights from partial deletion patients. Frontiers in Psychology, 3(168). doi: 10.3389/fpsyg.2012.00168

Karmiloff-Smith, A., Grant, J., Ewing, S., Carette, M., Metcalfe, K., Donnai, D. ... Tassabehji, M. (2003). Using case study comparisons to explore genotype-phenotype correlations in Williams-Beuren syndrome. Journal of Medical Genetics, 40, 136-140. doi: 10.1136/jmg.40.2.136

Kravitz, D., Saleem, K., Baker, C., \& Mishkin, M. (2011). A new neural framework for visuospatial processing. Nature Reviews, 12, 217-230. doi: 10.1038/nrn3008

Li, L., Huang, L., Luo, Y., Huang, X., Lin, S., \& Fang, Q. (2015). Differing microdeletion sizes and breakpoints in chromosome 7q11.23 in Williams-Beuren syndrome detected by chromosomal microarray analysis. Molecular Syndromology, 6, 268-275. doi: $10.1159 / 000443942$

Makeyev, A., Erdenechimeg, L., Mungunsukh, O., Roth, J., Enkhmandakh, B., Ruddle, F., \& Bayarsaihan, D. (2004). GTF2IRD2 is located in the Williams-Beuren syndrome critical region 7q11.23 and encodes a protein with two TFII-Ilike kelix-loop-helix repeats. Proceedings of the National Academy of Sciences of the United States of America, 101(30), 11052-11057.

Martens, M., Wilson, S., \& Reutens, D. (2008). Research review: Williams syndrome, a critical review of the cognitive, behavioral, and neuroanatomical phenotype. The Journal of Child Psychology and Psychiatry, 49, 576-608.
Matute, E., Rosselli, M., \& Ardila, A. (2014). Evaluación Neuropsicológica Infantil-II. México: Manual Moderno.

Mervis, C., \& Morris, C. A. (2007). Williams syndrome. In M. Mazzocco \& J. Ross (Eds.), Neurogenetic developmental disorders. London: The MIT Press.

Meyer-Linderberg, A., Kohn, P., Mervis, C., Kippenhan, J. S., Olsen, R., Morris, C. A., ... Berman, K. F. (2004). Neural basis of genetically determined visuospatial construction deficit in Williams syndrome. Neuron, 43, 623-631.

Meyer-Linderberg, A., Mervis, C., \& Berman, K. F. (2006). Neural mechanisms in Williams syndrome: A unique window to genetic influences on cognition and behaviour. Nature Reviews, 7, 380 393. doi: $10.1038 / \mathrm{nrn} 1906$

Mimura, M., Hoeft, F., Kato, M., Kobayashi, N., Sheau, K., Piggot, J., ... Reiss, A. (2010). A preliminary study of orbitofrontal activation and hypersociability in Williams Syndrome. Journal of Neurodevolopmental Disorders, 2, 93-98. doi:10.1007/s11689009-9041-8

Mobbs, D., Eckert, M., Menon, V., Mills, D., Korenberg, J., Galaburda, A., ... Reiss, A. (2007). Reduced parietal and visual cortical activation during global processing in Williams syndrome. Developmental Medicine Child Neurology, 49, 433-438.

Morris, C. A., Mervis, C., Hobart, H., Gregg, R., Bertrand, J., Ensing, G., ... Stock, D. (2003). GTF2I Hemizygosity implicated in mental retardation in Williams Syndrome: Genotypephenotype analysis of five families with deletions in the Williams Syndrome region. American Journal of Medical Genetics. Part A, 123A(1), 45-59. doi: 10.1002/ajmg.a.20496

Osborne, L. (2010). Animal models of Williams syndrome. American Journal of Medical Genetics. Part C, Seminars in Medical Genetics, 154C(2), 209-219. doi: 10.1002/ajmg.c.30257

Ostrosky-Solís, F., Guevara-López, U., \& Matute, E. (2012). Neuropsi Atención y Memoria. México: Manual Moderno.

Palmer, S., Taylor, K. M., Santucci, N., Widago, J., Chan, Y.-K. A., Yeo, J.-L., ... Hardeman, E. (2012). GTF2IRD2 from the Williams-Beuren critical region encodes a mobile-elementderived fusion protein that antagonizes the action of its related family members. Journal of Cell Science, 125, 5040-5050. doi: $10.1242 /$ jcs. 102798

Porter, M., \& Coltheart, M. (2006). Global and local processing in Williams syndrome, autism, and down syndrome: Perception, attention, and construction. Developmental Neuropsychology, 30 (3), 771-789. doi: 10.1207/s15326942dn3003_1

Porter, M., Dobson-Stone, C., Kwok, J., Schofield, P., Beckett, W., \& Tassabehji, M. (2012). A role of transcription factor GTF2IRD2 in Executive Function in Williams-Beuren Syndrome. PLoS One, 7(10). doi: 10.1371/journal.pone.0047457

Shamay-Tsoory, S. G., Tomer, R., Goldsher, D., Berger, B. D., \& Aharon-Peretz, J. (2004). Impairment in cognitive and affective empathy in patients with brain lesions: Anatomical and cognitive correlates. Journal of Clinical and Experimental Neuropsychology, 26(8), 1113-1127.

Tassabehji, M., Metcalfe, K., Karmiloff-Smith, A., Carette, M., Grant, J., Dennis, N., ... Donnai, D. (1999). Williams syndrome: Use of chromosomal microdeletions as a toll to dissect cognitive and physical phenotypes. American Journal of Human Genetics, 64, 118-125.

Tipney, H., Hinsley, T., Brass, A., Metcalfe, K., Donnai, D., \& Tassabehji, M. (2004). Isolation and characterisation of GTF2IRD2, a novel fusion gene and member of the TFII-I family of transcription factors, deleted in Williams-Beuren syndrome. European Jorunal of Human Genetics, 12, 551-560. 
Uhlén, M., Fagerberg, L., Hallström, B., Lindskog, C., Oksvold, P., Mardinoglu, A., ... Fredrik, P. (2015). Tissue-based map of the human proteome. Science, 347(6620), 1260419. doi: 10.1126/ science. 1260419

Vandeweyer, G., Van der Aa, N., Reyniers, E., \& Kooy, , F. (2012). The contribution of CLIP2 haploinsuffieciency to the clinical manifestations of the Williams-Beurens syndrome. The American Journal of Human Genetics, 90, 1071-1078. doi: 10.1016/j.aj hg.2012.04.02.

Venegas Vega, C. A. (2012). Pruebas citogenéticas basadas en microarreglos. In V. Del Castillo Ruiz, R. D. Uranga Hernández, \& G. Zafra de la Rosa (Eds.), Genética Clínica. México: Manual Moderno.

Wang, Y.-K., Spörle, R., Paperna, T., Schughart, K., \& Francke, U. (1999). Characterization and expression pattern of the frizzled Gene Fzd9, the mouse homolog of FZD9 whics is deleted in Williams-Beuren Syndrome. Genomics, 57, 235-248.

Wechsler, D. (2007). Escala Wechsler de Inteligencia para Niños y Adolescentes-IV. México: Manual Moderno.

Wechsler, D. (2014). Escala Wechsler de Inteligencia para AdultosIV. México: Manual Moderno.

Young, E. J., Lipina, T., Tam, E., Mandel, A., Clapcote, S. J., Bechard, A. R., ... Osborne, L. (2008). Reduced fear and aggression and altered serotonin metabolism in GTF2IRD1targeted mice. Genes, Brain and Behavior, 7, 224-234. doi: 10.1111/j.1601-183X.2007.00343.x

Zhang, Y., Chen, K., Sloan, S. A., Bennett, M. L., Schoize, A. R., O'Keefe, S., . . . ... Wu, J. Q. (2014). An RNA-sequencing transcriptome and splicing database of glia, neurons, and vascular cells of the cerebral cortex. Journal of Neuroscience, 34(36), 1192911947. doi: https://doi.org/10.1523/JNEUROSCI.1860-14.2014 